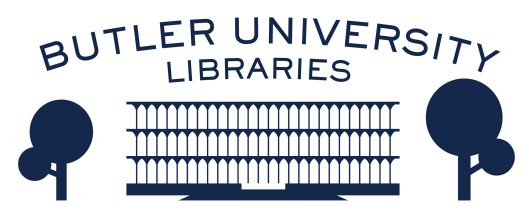

Journal of Hindu-Christian Studies

Volume 5

Article 13

January 1992

\title{
Book Review: "The Role of Pramanas in Hindu-Christian Epistemology"
}

Anand Amaladass

Follow this and additional works at: https://digitalcommons.butler.edu/jhcs

Part of the Religion Commons

\section{Recommended Citation}

Amaladass, Anand (1992) "Book Review: "The Role of Pramanas in Hindu-Christian Epistemology"," Journal of Hindu-Christian Studies: Vol. 5, Article 13.

Available at: https://doi.org/10.7825/2164-6279.1066

The Journal of Hindu-Christian Studies is a publication of the Society for Hindu-Christian Studies. The digital version is made available by Digital Commons @ Butler University. For questions about the Journal or the Society, please contact cbauman@butler.edu. For more information about Digital Commons @ Butler University, please contact digitalscholarship@butler.edu. 
contemporary situation, symbolised by this international, interreligious seminar, is that whether we like it or not we are thrown together in this task. Sometimes even those of us who live daily in multi-religious contexts forget the implications of this "togetherness." The search for new patterns of relationships is not the prerogative of any one particular community of faith.

However, despite its shortcomings, there is much to be gained in terms of fellowship and insight from such dialogue meetings and the publication of their proceedings. Both the meetings and the sharing of wisdom need to be encouraged, pressing forward towards the ful fillment of the vision of a world community characterised by peace with justice which is a guiding light for all religious communities. In this quest, there are things to be learned from the present undaunted attempt to shed light from the various religious traditions on the articulation of this vision in the expectation of furthering the struggle for its achievement. We are in the debt of both the participants and the editor.

David C. Scott

United Theological College

Bangalore

\section{The Role of Pramānas in Hindu-Christian Epistemology. K.P. Aleaz. Punthi-Pustak, Calcutta, 1991, 154p.}

THE aUthor states his objective as discovering the six Indian pramānas as "an authentic aspect of Indian Christian Theological method vis-a-vis the Christian pramānas as understood by some Indian Christian theologians." (p.3) He finds that the earlier attempts in this direction do not take into account the six pramannas of Indian philosophy and their possible use as Christian pramannas. As the title of the book stands, the project itself is laudable and one would expect a breakthrough in a theological method building upon the earlier attempts.

In the process of inculturation there was a stage where equivalents of Christian tradition were sought in Hindu tradition, to adapt, if not adopt fully, for the enrichment of the Indian Christian theology. And in that sense it is valuable to look into the six traditional sources of knowledge-pramānas-from which Christianity could gain some insight into its own tradition. So the author examines the six means of knowing and appeals to the Christian community that these should be used in theological reflection. But as such it does not offer any further reflection on the possible gains through this method.

It is high time to go beyond this stage and see what response the metaphors of one tradition evoke in another tradition, with a view to develop an inter-cultural and inter-religious concept of pramānas - as a precondition for the meeting of cultures and religions, so that dialogue between traditions is possible without losing their identity. But the author tends to be descriptive rather than addressing himself to the larger issues of Hindu-Christian epistemology while dealing with the role of pramānas.

Any theological method takes into account revelation, reason, and experience. Even within a particular religious framework, for example in Hinduism, revelation is differently interpreted, depending on the specific tradition one comes from-as in the case of the Vedantins. Tradition is always a complex whole. In Christianity what is meant by religious tradition depends on the core of the basic beliefs which have their point of reference to scriptures, teaching authority, saints and enlightened leaders of this tradition, liturgy 
40 Book Reviews

and also the consensus of believers. Even here it is not the content but a common horizon that determines the identity of this or any tradition.

So when one talks of a theological method, one has to take into account how the Hindu thinkers went about with their task of theologizing. It is true the six pramānas are used by the Vedantins. But they give their priority to perception, revelation and inference over the rest. The Vedantins also differ among themselves in the way they use the tradition they come from, and in the sources that are quoted by them. So when a Christian believer theologizes, he will also be discrete in the use of his own inherited tradition while being open to the models available in the Indian traditions. So there is no point in saying that "one cannot add more pramānas." "Tradition cannot be presented as one of the pramannas" (p. 119), "śabhã cannot be a pramāna" and so on. They are certainly factors that should find a place in any theological method whether one calls it a pramāna or not. And one need not, for example, press into service a pramāna like anupalabdhi (non-cognition) explicitly by its name in order to say that "the caste system in India and the consequent socio-economic injustice done to the dalits are the expressions of the non-existence of goodness and this we know through the valid source of knowledge non-cognition." (p. 128)

The author draws our attention to make use of the various insights gained through the development of language studies in the Indian tradition. It is true that Indian tradition developed its language philosophy as an exegetical tool to understand the Scriptures. The function of the primary meaning (abhidhā) and secondary meaning (laksañā) and so on. Attempts have been made already to bring in dhvani theory to interpret the Scriptures in the Indian context, though it has not been further developed. (Cf. Biblebhäshyam: An Indian Biblical Quarterly. Kottayam. December 1979).

In fact Dr. Somen Das in his foreword to this book very perceptively points out some of the areas to which the author of this book should pay (or should have paid) attention. Otherwise publications on inter-religious or inter-cultural studies are bound to remain at the initial stage without further probing into the crucial issues that one would expect from the committed thinkers.

Anand Amaladass

Satyanilayam

Madras

\section{Pilgrims of Dialogiee. A. Pushparajan (ed). Munnar: Sangam Dialogue Centre,} 1991, 243p, Rs. 80.

TORTY SCHOLARS INVOLVED in interfaith dialogue have contributed to a Festschrift honouring Fr. Albert Nambiaparambil, CMI, Secretary of the CBCI Commission for Dialogue on the occasion of his completing 60 years of age. In Indian Shashtiaptha Poorthi is an auspicious event, worthy of public celebration. Since Fr. Albert has been engaged in promoting dialogue ministry in India, Dr. A. Pushparajan (Reader in Gandhian Studies, Madurai-Kamaraj Univer- sity and Secretary of Madurai Diocesan Commission for Dialogue) thought it fit to bring out a book on Dialogue experiences.

There are five sections: Pioneers and On Pioneers, Organizational Dialogue, Ashram Experience, Personal Testimonies and Theoretical Reflections. It is not a strict division since practically all write from a context of personal experience, particularly having had some inspiration from Fr. Albert. The list of contributors gives a fair sample of persons, 